\section{Everyday Miracles}

"Thanks. That's just what I needed. You are a miracle worker!"

"This library is useless. I'm never coming back here again."

—anonymous library users
David A. Tyckoson, 2007-2008

President of the Reference and User

Services Association, is Associate Dean,

Henry Madden Library, California State

University, Fresno; e-mail: davety@

csufresno.edu.

\section{I}

n my previous column, I presented four memorable reference encounters that I have had with users over the past three decades. ${ }^{1}$ Those examples highlighted the complexity of the interaction between the librarian and the user and raised the question of the changing nature of the definition of quality service. The lesson to be learned from that column is that our interactions with our users are complex and that the meaning of the work that we do needs to be interpreted in the light of the user's individual perspective. In this column, I would like to focus more on the common, everyday interactions that we have with our users and how those interactions affect—and strengthen-our local communities.

A researcher needs documentation of some specific impacts of global warming on the arctic. The librarian not only helps him find articles online, but also shows him how to send them to his home e-mail and download them onto his flash drive.

If your experience is like mine (and I am willing to bet that it is very similar to mine), you have heard each of the two user responses quoted above. And if your experience is like mine, you have been a miracle worker-or a similar name to that effect-far more often than you have been a useless loser. This reflects the fact that as librarians we know a wide range of information sources, we are excellent searchers, and we are able to use the techniques of the reference interview to identify what our users really want-even when they may not know what they are looking for themselves.

An immigrant couple is having a hard time figuring out how to fill out their tax forms. The librarian steers them towards the AARP volunteers who provide tax assistance in the "Tax Help@Your Library" program. They also learn how to file online and get their refund check within a couple of weeks.

Through a combination of education and experience, we have learned how to interact with our users in such a way that wins their respect and confidence. We use the classic techniques of open- and closed-ended questioning to understand users' questions. We instruct users about the research process while we are answering their questions. We help users think critically to determine which information sources are the most relevant and most reliable. We direct users to the books, databases, journals, and Web sites that are most relevant to their needs. We recommend everything from clas- 


\section{FROM THE PRESIDENT OF RUSA}

sic pieces of literature to romance novels. We help the user standing in front of us, but we also help users anywhere in the world who contact us via the phone, e-mail, chat, and instant messenger.

A senior citizen who is not very familiar with computers wants to learn about the latest social networking software to keep in touch with her granddaughter who is in the Army and stationed in the Middle East. The librarian signs her up for the workshop that is scheduled for next Saturday, where she learns how to go to her granddaughter's page, read her blog, and watch her videos.

We do all of this and more-over and over again every day. From our perspective, it almost becomes routine. We might help one user with a tax law question, help the next one identify a good mystery novel, fix the next user's printer, and teach someone else how to use Pubmed, all within a span of a few minutes. This is simply what we do as librarians and we see it as no big deal. In the course of these daily activities, we can lose track of how they have a real impact on our users' lives.

A newly hired Kindergarten teacher needs lesson plans for art projects that meet current state curriculum standards. The librarian links her to the librarian-produced Kindergarten Teacher Web site, which not only provides online lesson plans, but links to the standards themselves.

Library users are not just some random sample of people who happen to walk into the library or who contact it remotely. They are our community. Most users are the residents, students, teachers, or researchers for whom the library was established. In a public library, they are the citizens of a specific city, county, or town. In an academic library, they are the faculty, staff, and students of the college or university. In a medical library, they are the doctors, nurses, and patients of the hospital or clinic. In a school library, they are the teachers and students of that school. With very few exceptions, every library was established to serve a defined community of people. Most of the users of that library come from within that community.

An English-language-learning adult comes to the library to find books that he can read at his level. The librarian provides him with some graphic novels to get him started. Throughout the year, he keeps coming back asking for suggestions. He progresses through young adult literature, fantasy, and science fiction, and into scholarly works on philosophy and religion. Even when he no longer needs the librarian's help, he stops by to thank her for getting him started.

Of course, we librarians tend to be of a generous nature, so we help pretty much anyone, whether they are members of our primary community or not. The growth of reciprocal borrowing, interlibrary loan, resource sharing, and consortial reference services reflects that generosity. We share our resources and our services with other libraries and individuals on a regular basis. In fact, we may be the most cooperative profession in existence. But, when all is said and done, it is our service to our primary clientele that determines if a library will thrive. It is our local community's assessment of our value that designates whether the library succeeds or fails as an institution.

A laid-off maintenance worker needs help finding a new job. The library career center helps him find leads, evaluate his skills, and write a resume. He soon finds an even higher paying job working for the county.

There have been many methods developed for measuring reference success. In the 1980s, unobtrusive testing was hot. The famous 55 Percent Rule came out of this movement - and that finding did not make us look very good. ${ }^{2}$ Joan Durrance's Willingness to Return studies and the Wisconsin-Ohio Reference Evaluation Program followed. ${ }^{3}$ Although they also indicated that we are only correct slightly more than onehalf of the time, at least they provided reasons why reference staff found the right answer (or not). Obtrusive evaluation has recently surfaced as a standard means of reference evaluation, particularly for chat reference. ${ }^{4}$ By reading the actual transcripts of librarian-user interactions, we can identify the precise actions (or lack thereof) that contribute to positive or negative results. LibQUAL tells us not only whether our users are satisfied with our services, but whether they see them as important. ${ }^{5}$ We are using increasingly sophisticated and targeted tools to help us measure our services and the data that we gather from those tools helps us to continually improve what we do.

A middle school student asks over the library's chat reference service how to find books about the history of banking. The librarian finds several titles that sound appropriate and teaches the student how to order them for delivery at her local branch library. She later gets an "A" on her paper.

But those measures are often focused on how we librarians see our services rather than on how our users see them. For our users, interest in the library is at a very personal level. What

\section{EXAMPLES OF EVERYDAY MIRACLES}

Interspersed with my text are samples of situations common in libraries. Although I made up these vignettes, they are representative of real encounters that librarians have with users on a regular basis. My examples tend to be public library oriented, but similar events happen in libraries of all types. They might be routine transactions to us, but they can be life-changing from the user's perspective. In the eyes of our users, we do perform miracles every day. 
is important to the user is that the library is able to satisfy a very specific need at a very specific time. Librarians work at the library, but users experience the library. It is those hundreds and thousands of unique, individual experiences that make the library a success or a failure. From what I see when I visit libraries of various types in various places, those libraries are a resounding success. In communities of all types and locations, the library is consistently rated as one of the best and most important institutions by local community members.

A middle aged man who is restoring a '68 Mustang needs a wiring diagram for the electrical system in the dashboard. The librarian finds the call number for one of the volumes of Chilton's that covers that make and model and helps him find it on the shelves.

We tend to take it for granted, but we need to remind ourselves of the importance and value of what we are doing for our communities. What to us might be a routine or common question can be a life-changing event for our users. Librarians are not often viewed as heroes because we do not pull people out of burning buildings, catch robbers, or stop terrorists. What we do for our communities is equally as important, but less dramatic. Librarians may not save lives, but we certainly shape lives. Through our literacy programs, career services, voter registration, parenting classes, and reference assistance, we are building a better community one person at a time. In many ways, we do save lives-but we save them before they reach the point where that saving requires crisis intervention.

A class of college students is working on criticism of the poems of Robert Frost. The librarian goes to their classroom, shows them how to use the MLA Bibliography, and prepares a Web page that the students can go back to throughout the semester for additional help. The professor comments that his students wrote better papers than he had read in the past and signs up the librarian to come back to the class next semester.

As librarians, we all like to have the latest Web pages, the latest search software, the coolest communication technology, the biggest building, and the best books and journals. We tend to focus on those features because those are the tools of our trade. While users also may take an interest in those things, they focus much more closely on the people behind the tools-us. Users may not remember the specific book, journal, Web page, or database that answered a question that they had at some past time, but they certainly will remember the face of the librarian who helped them. It is not the tool, but the encounter that matters to the user. Users like libraries not because of our materials or our technologies, but because of the truly human aspect of our service.

The young adult librarian shows the "Lord of the Rings" trilogy over a period of three weeks. She also brings copies of the books and makes a list of other authors with a similar style. At the end of the film series, all of the books on her bibliography are checked out and the teens have started their own discussion group.

Looking back at the two quotes that started this column, I realize that there are times when I cannot help someone and I do leave them with that useless feeling. But most of the time I really can help the user, and I could be perceived as a miracle worker. I am sure that you have experienced the same. As a result of those little miracles, we librarians are building better communities and a better society. It is not the grand ideas that make us relevant to our users, although we certainly should never stop dreaming of ways to make the library a better institution. It is rather our everyday activities that make us heroes to our users.

A young mother brings her two obviously active toddlers into the library. They listen to the story hour, where the children become entranced by the tales of magical lands, fairies, and princesses. Afterwards, they go to the shelves and the children each get to select several books. They are truly excited about the library as they leave the building and the mother promises to read them a story as soon as they get home.

In the very first article ever written about reference services, Samuel Green discussed how interaction with the user was in and of itself a way to promote the community within the library. ${ }^{6}$ As a young reference librarian, I never thought much about that concept. As time has passed, I have come to realize that this is the single most significant component of our services. Our success is not measured through the answers that we give, the classes we teach, the books that we buy, or the software that we develop, but through the human connections that we make in the process of interacting with our users. As long as we can keep performing those everyday miracles for members of our local communities, our future will be assured.

\section{References}

1. David A. Tyckoson, "Why is Germany in Europe? And Other Lessons from a Life in Reference," Reference \& User Services Quarterly 47, no. 3 (Spring 2008): 7-9.

2. Peter Hernon and Charles McClure, "Unobtrusive Reference Testing: The 55 Percent Rule," Library Journal 111 (April 15, 1986): 37-41.

3. Joan C. Durrance, "Factors that Influence Reference Success: What Makes Questioners Willing to Return?" Reference Librarian no. 49/50 (1995): 243-65; and Wisconsin-Ohio Reference Evaluation Program, http://worep.library.kent/edu (accessed Feb. 1, 2008).

4. Carol Tenopir, "What Chat Transcripts Reveal," Library Journal 131 (Mar. 1, 2006): 34.

5. LibQUAL+, www.libqual.org (accessed Feb. 1, 2008).

6. Samuel Swett Green, "Personal Reflections Between Librarians and Readers." Library Journal 1 (Oct. 1876): 74-81. 